\title{
Removal of Nitramine Explosives in Aqueous Solution by UV-Mediated Advanced Oxidation Process in Near-Neutral Conditions
}

\author{
Do Ngoc Khue', Vu Quang Bach², Nguyen Thanh Binh³, Do Binh Minh', \\ Pham Thi Nam ${ }^{4}$, Vu Duc Loi ${ }^{5}$, Hoa Thanh Nguyen ${ }^{6 *}$ \\ 1 Institute of New Technology, Academy of Military Science and Technology, 17 Hoang Sam str., Ha Noi, Viet Nam \\ 2 Military Industrial College, 22/103 Ly Son str, Ngoc Thuy, Long Bien, Ha Noi, Viet Nam \\ ${ }^{3}$ College of Chemical Defense Officer/Chemical Corps; Tan Phu, Son Tay dictrict, Ha Noi, Viet Nam \\ ${ }^{4}$ Institute For Tropical Technology, Vietnam Academy of Science and Technology, 18 Hoang Quoc Viet str., \\ Ha Noi, Viet Nam \\ ${ }^{5}$ Institute of Chemistry, Vietnam Academy of Science and Technology, 18 Hoang Quoc Viet str., Ha Noi, Viet Nam \\ 6 Thuyloi University, 175 Tay Son str., Dong Da, Ha Noi, Viet Nam \\ * Corresponding author's email: nthoa@tlu.edu.vn
}

\begin{abstract}
Explosive compounds are hazardous to the environment, posing a serious risk to human and animal health and the ecosystem. The primary goal of research was to compare the efficiency of $\mathrm{UV} / \mathrm{H}_{2} \mathrm{O}_{2}$, photo-Fenton, electro (EO)/ $\mathrm{UV} / \mathrm{H}_{2} \mathrm{O}_{2}$ processes at near-neutral $\mathrm{pH}(\mathrm{pH}=6)$ on the degradation of nitramine explosives (NAs), such as hexogen (RDX), octogen (HMX), and tetryl (TET), in an aqueous solution. The effect of operational conditions, likely $\mathrm{pH}$ of the solution, initial $\mathrm{H}_{2} \mathrm{O}_{2}$ concentration, initial $\mathrm{Fe}^{2+}$ concentration, and solution temperature, was observed. The removal kinetics fit with first-order kinetics and were in the order: photo-Fenton $>\mathrm{EO} / \mathrm{UV} / \mathrm{H}_{2} \mathrm{O}_{2}>\mathrm{UV} / \mathrm{H}_{2} \mathrm{O}_{2}$. The results showed higher rate constant values for TET, RDX and $\mathrm{HMX}$ removal by $\mathrm{UV} / \mathrm{H}_{2} \mathrm{O}_{2}(\mathrm{k}=0.07778,0.03791$ and $\left.0.03786 \mathrm{~min}^{-1}\right), \mathrm{EO} / \mathrm{UV} / \mathrm{H}_{2} \mathrm{O}_{2}\left(\mathrm{k}=0.16599,0.1475\right.$ and $\left.0.08674 \mathrm{~min}^{-1}\right)$ and photo-Fenton $(\mathrm{k}=0.18018,0.1501$ and $0.09336 \mathrm{~min}^{-1}$ ) processes. Furthermore, TET, RDX and HMX were mineralized at 59.7\%, 45.1\%, and $25.1 \%$, respectively, under optimum conditions after $60 \mathrm{~min}$ of the photo-Fenton process. From the economic perspective, photo-Fenton only requires $2.132-4.113 \mathrm{kWh} \mathrm{m}^{-3}$ to completely reduce NAs. Finally, acute toxicity towards Vibrio fischeri was defeated after usage of near-neutral photo-Fenton. Thus, photo-Fenton at circum-neutral is promising for low-cost, eco-friendly and efficient processes for treating nitramine explosives in aqueous solutions.
\end{abstract}

Keywords: Hexogen, Octogen, Tetryl, UV, photo-Fenton, electro-oxidation, near neutral.

\section{INTRODUCTION}

Nitramine compounds (NAs), such as hexogen (cyclotrimethylene trinitramine, RDX), octogen (cyclotrimethylene trinitramine, HMX), tetryl (2,4,6-trinitrophenyl-N-methylnitramine, TET) are commonly used as explosives. Their molecular structures are described in Table 1. These nitramine compounds contaminate wastewater from some industrial explosive production lines that make ammunition for military use. TET is mainly employed as a booster charge to propagate detonation in the main charge, while RDX and HMX are used in bombs, torpedoes, and armour-piercing shells. NAs cause harm to human health, animals, and ecosystems. LewisYounger et al. (2000) investigated the toxic effect of nitramine explosives on workers in explosives plant; their results showed that TET caused dermatitis in 61 of the employees. At the same time, RDX was identified as the cause of nausea, dizziness, convulsions, vomiting, and headaches. Some by-products of RDX and HMX degradation are carcinogens or mutagens; for example, 
Table 1. The detailed structure of TET, RDX, and HMX

\begin{tabular}{|c|c|c|c|}
\hline NAs & Molecular structure & Molecular formula & Molar mass $(\mathrm{g} / \mathrm{mol})$ \\
\hline Hexogen (RDX) & & $\mathrm{C}_{3} \mathrm{H}_{6} \mathrm{~N}_{6} \mathrm{O}_{6}$ & 222.12 \\
\hline Octogen (HMX) & & $\mathrm{C}_{4} \mathrm{H}_{8} \mathrm{~N}_{8} \mathrm{O}_{8}$ & 296.16 \\
\hline Tetryl (TET) & & $\mathrm{C}_{7} \mathrm{H}_{5} \mathrm{~N}_{5} \mathrm{O}_{8}$ & 287.14 \\
\hline
\end{tabular}

1,2-dimethylhydrazine is known to cause cancer in rats (Fiala, 1977). Previous research showed that methanol, 1,1-dimethylhydrazine, hydrazine, and formaldehyde are derivatives of RDX (Freedman and Sutherland, 1998). Thus, by-products from RDX and HMX must be closely monitored and remediated in the environment (Liou et al. 2003).

In recent years, the treatment of NAs-contaminated water has been carried out using a variety of methods, such as adsorption (Lingamdinne et al., 2015), hydrolysis (Bishop et al.2000), wet oxidation (Hao and Phull, 1993), and biological treatment (Cyplik et al. 2012). However, these processes have many disadvantages, including long duration for biological treatment, high pressure and temperature demands for wet air oxidation, and incomplete contaminant removal for the adsorption process (Bhaskar Raju et al. 2011). For instance, complete denitrification took 13 days using anaerobic bacteria DeNitrifying Consortium 2 (Cyplik et al. 2012). However, advanced oxidation processes (AOPs) are promising technologies that aim to decompose and mineralize potential-contaminants into non-toxic products (Andreozzi et al., 1999). AOPs involve various methods leading to the production of free radicals, such as hydroxyl radicals $\left(\mathrm{HO}^{*}\right)$ and sulphate radicals $\left(\mathrm{SO}_{4}{ }^{*-}\right), \mathrm{O}_{2}{ }^{*}, \mathrm{HO}_{2}{ }^{*}$ etc., which can oxidize contaminants and treat wastewater (Radovic et al. 2015). Many researchers have applied electrochemical technology (EO) as a simple, safe, and environmentally-friendly process for the removal of various pollutants from aquatic environments (Dalvand et al. 2011, Martínez-Huitle et al. 2012). Furthermore, the benefits of electro-oxidation compared to other AOPs are limited sludge and salt formation, noticeably safe and simple operation, fast reaction, and significant reduction of total organic carbon (TOC). Electrochemical technology, using electrolysis, can be coupled with UV light for methanol removal (Odetola, Trevani and Easton, 2017) or amoxicillin degradation in water (Fallahzadeh et al.2019). This phenomenon explains the potential of the products to remove pollutants by way of free radicals from the electrooxidation process.

The application of photodegradation processes, such as $\mathrm{UV} / \mathrm{H}_{2} \mathrm{O}_{2}$ and $\mathrm{UV} / \mathrm{H}_{2} \mathrm{O}_{2} / \mathrm{Fe}^{2+}$ (photoFenton), have gained attention due to their efficient removal of different pollutants, including explosives (Liou et al. 2003, Khue et al. 2016, Khue et al. 2018). The reaction mechanism leading to hydroxyl radical $\left(\mathrm{HO}^{*}\right)$ production from $\mathrm{H}_{2} \mathrm{O}_{2}$ during the photo-Fenton process is shown by Eq. (1) and Eq. (2) (Clarizia et al., 2017): 


$$
\begin{gathered}
\mathrm{Fe}^{2+}+\mathrm{H}_{2} \mathrm{O}_{2} \rightarrow \mathrm{Fe}^{3+}+\mathrm{HO}^{*}+\mathrm{OH}^{-} \\
\mathrm{Fe}^{3+}+\mathrm{hv}+\mathrm{H}_{2} \mathrm{O} \rightarrow \mathrm{Fe}^{2+}+\mathrm{HO}^{*}+\mathrm{H}^{+}
\end{gathered}
$$

Nonetheless, there are some disadvantages, including an acidic $\mathrm{pH}$ value (2.8-3.5), which is needed to ensure that $\mathrm{Fe}$ (II) and $\mathrm{Fe}(\mathrm{III})$ ions enhance the catalytic effect, thus limiting iron oxyhydroxides $\mathrm{Fe}(\mathrm{OH})_{3}$ and exaggerating the concentration of photo-promoted electrons. The feasibility of working at near-neutral pH (5.0-6.0) has provoked interest from researchers (Dantas and Esplugas, 2014). According to Zhai et al. (2018), the reduction of natural gas extraction wastewater was achieved at the optimal $\mathrm{pH}$ at 6 using a photo-Fenton process. The using of "low cost reactors" at neutral $\mathrm{pH}$ for elimination of emerging pollutants was checked out by SarinaMolina et al. and it also uncovered that they could evaculate $80 \%$ of them within 15 min of therapy. In order to being used by more rural societies for drinking water, it is nescessary for optimization of the system at a neutral or near neutral. A various of chemical methods, which would request time, noticeable attempt and reduce chemical's costs, will be implemented by the communitites (Soriano-Molina et al. 2019).

Use of a photo-Fenton reaction, an AOP, leads to total pollutant mineralization. However, partial mineralization can generate by-products which are more noxious than the original species. In some cases, the increase in toxins appeared after pre-treatment using a photo-Fenton reaction of toxic effluent (Carra et al. 2015). Since a biological response reflects the level of toxicity, various organisms can be applied to improve the reliability of the results.

Organisms applied in bioassays for toxicity involve typical samples of seawater, freshwater, or terrestrial ecosystems, including microorganisms, plants, invertebrates and fish (Tothill and Turner 1996). It is beneficial to control the processes and compare various AOPs when evaluating the toxicity of treatments using bioassays with different types of organisms (Rizzo, 2011). Luminescent microorganisms, namely Vibrio fischeri ( $V$. fischeri) bacteria, have often been applied in toxicity test instruments (Rizzo, 2011). These tests are based on the shift in bacterial luminescence when exposed to toxic chemicals. Simplicity and short timeframe are the main benefit of these tests.

There are only a few studies regarding NA degradation in water by AOPs assisted by UV light and an EO process in circum-neutral conditions. This research aims to assess the efficiency of three AOPs processes in the degradation of NAs compounds: $\mathrm{UV} / \mathrm{H}_{2} \mathrm{O}_{2}, \mathrm{UV} / \mathrm{EO} / \mathrm{H}_{2} \mathrm{O}_{2}$ and photo-Fenton. The influence of parameters such as $\mathrm{H}_{2} \mathrm{O}_{2}$ concentration, ratio $\mathrm{H}_{2} \mathrm{O}_{2} / \mathrm{Fe}^{2+}$, and temperature of the experiments on the degradation of NAs was investigated. Also, the efficiency and electric energy consumption of the three AOPs was compared. Finally, mineralization and toxicity were evaluated with V.fischeri bacteria of the circum-neutral photo-Fenton process.

\section{MATERIALS AND METHODS}

\section{Chemicals}

Crystalline $\mathrm{RDX}\left(\mathrm{C}_{3} \mathrm{H}_{6} \mathrm{~N}_{6} \mathrm{O}_{6}\right)$ (purity 99\%), $\mathrm{HMX}\left(\mathrm{C}_{4} \mathrm{H}_{8} \mathrm{~N}_{8} \mathrm{O}_{8}\right)(99 \%)$ and TET $\left(\mathrm{C}_{7} \mathrm{H}_{5} \mathrm{~N}_{5} \mathrm{O}_{8}\right)$ (99\%) were purchased from Merck (Merck KGaA, Germany). Reagents for AOPs were $\mathrm{FeSO}_{4} \cdot 7 \mathrm{H}_{2} \mathrm{O}$, hydrogen peroxide $\left(\mathrm{H}_{2} \mathrm{O}_{2} 30 \%\right)$ and $\mathrm{NaCl}$, supplied by Sigma-Aldrich (Merck, Germany) and Acros Organics (Thermo Fisher Scientific, USA), respectively. All solvents (acetonitrile, ethanol, methanol, and hexane) used in high-performance liquid chromatography (HPLC) were of analytical grade.

\section{Continuous-flow experiments}

All experiments were carried out in a circulatory photoreactor system, following Khue et al. (2014), as shown in Figure 1.

All solutions in the AOP experiments were prepared using distilled water and the $\mathrm{pH}$ was maintained at 6.0, applying either $\mathrm{NaOH} 0.1 \mathrm{M}$ or $\mathrm{H}_{2} \mathrm{SO}_{4} 0.1 \mathrm{M}$. An oxidising agent was added to the NAs solution ([TET] $=38.46 \mathrm{mg} \mathrm{L}^{-1}$, [RDX] $\left.=19.22 \mathrm{mg} \mathrm{L}^{-1},[\mathrm{HMX}]=5.28 \mathrm{mg} \mathrm{L}^{-1}\right) ; \mathrm{H}_{2} \mathrm{O}_{2}$ or Fenton's reagent was placed into the reactor tank/ electrochemical reactor $(500 \mathrm{~mL})$ with a heating magnetic stirrer Are-6 (Velf scientifica, Italy). All NAs solution samples were measured by a pH meter (Milwaukee 102, Poland). The solution was mixed by heating, with the magnetic stirrer at $300 \mathrm{rpm}$ during the experiment, and circulated through a UV reaction chamber with a $15 \mathrm{~W}$ UV light lamp (Philips, Netherland) (radiation wavelength $254 \mathrm{~nm}$ ) applying a dosing pump (Hanna BL 20-2, Hanna Instruments, Romania) at a flow

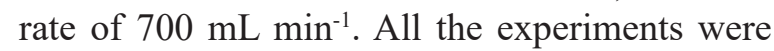
conducted in triplicate. 


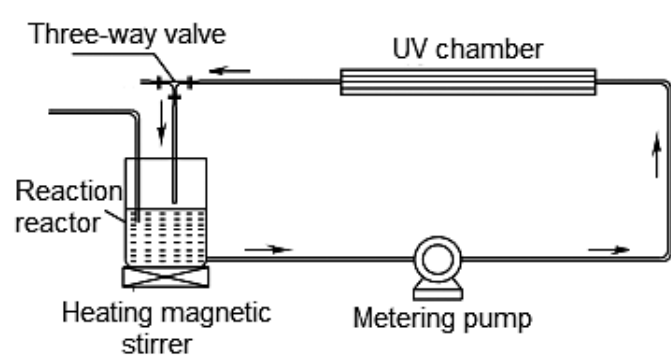

(a)

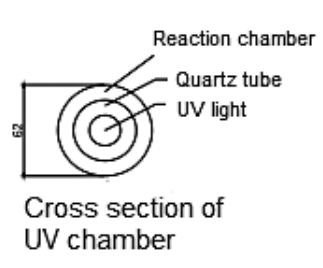

Electrooxidation reactor

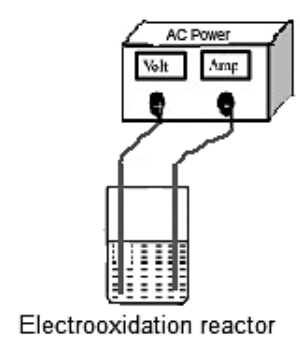

(b)

Fig. 1. Schema of circulatory photoreactor system

\section{Electro-oxidation reactor}

In the case of $\mathrm{UV} / \mathrm{EO} / \mathrm{H}_{2} \mathrm{O}_{2}$, an electrochemical reactor $(500 \mathrm{~mL})$ (Fig. 1b) in which the anode and cathode were $1 \mathrm{~mm}$ thick Ti plates $(4 \mathrm{~cm} \times$ $20 \mathrm{~cm}$ ) covered with $\mathrm{TiO}_{2}$ and $\mathrm{RuO}_{2} / \mathrm{IrO}_{2}$ (Inox) was used. The interelectrode distance between anode and cathode was $2 \mathrm{~cm}$. AC power supply (Model 1655A, B\&K Precision, USA) with a current density of $15 \mathrm{~mA} \mathrm{~cm}^{-2}$ was supplied for this electro-oxidation system. $3 \mathrm{~g} \mathrm{~L}^{-1} \mathrm{NaCl}$ was used as electrolyte concentration in the electrooxidation process.

\section{Analytical methods}

\section{NAs determination}

Three NAs compounds: TET, RDX, and HMX were measured by HPLC system (HP-Agilent 1100 series, diode array detector, Agilent, USA), applying Hypersil C18 column (200 mm $\times 4 \mathrm{~mm}$ ). The mobile phase was made up of $67 \%$ acetonitrile and $33 \%$ water $(\mathrm{v} / \mathrm{v})$ at a flow rate of $0.6 \mathrm{~mL} / \mathrm{min}$, with a pressure of 280 Bars. The analytical signal was determined at a wavelength of $227 \mathrm{~nm}$ and retention times $\left(\mathrm{t}_{\mathrm{R}}\right)$ for TET, RDX and HMX at $5.7 \mathrm{~min}, 5.11 \mathrm{~min}$ and $4.7 \mathrm{~min}$, respectively (Khue et al. 2014).

\section{TOC determination}

The total organic carbon (TOC) was measured by Torch Combustion Analyzer (Torch, Teledyne Tekmar, USA).

\section{V. fischeri acute toxicity}

The standard ISO 1348-3:2007 (International Organization for Standardization, 2007) was used for the luminescence inhibition test with $V$. fischeri at 30 min after treatment $0,15,30$ and $60 \mathrm{~min}$ with the photo-Fenton process, with the
Microtox SOLO freeze-dried bacteria kit. The bacteria were carefully preserved at $-20^{\circ} \mathrm{C}$ and activated by hydration according to the kit's standard operation procedure. All samples were tested in triplicate and kept on a thermostatic plate at $15^{\circ} \mathrm{C}$ throughout the test period. The control sample used a solution of $20 \mathrm{~g} \mathrm{~L}^{-1} \mathrm{NaCl}$ (Acros, USA). After $30 \mathrm{~min}$, bioluminescence was measured with a Delta ATP illuminometer (Modern Water, USA).

The bioluminescence inhibition ratio (BIR) (\%) was calculated using Eq. (3):

$$
B I R=\frac{L_{\text {Blank }}-L_{\text {sample }}}{L_{\text {Blank }}}
$$

where: $\mathrm{L}_{\text {Blank }}$ and $\mathrm{L}_{\text {sample }}$ are the bioluminescence signals after $30 \mathrm{~min}$ of exposure for the sample without NAs and tested samples, respectively.

The removal efficiency $(\mathrm{H}(\%))$ of NAs and TOC removal by three Aops is calculated by equation Eq. (4):

$$
\mathrm{H}=\left\{\left(\mathrm{C}_{(0)}-\mathrm{C}_{(\mathrm{t})}\right) / \mathrm{C}_{(0)}\right\} \times 100 \%
$$

where: $\mathrm{H}(\%)$ is the efficiency of NAs removal

$\mathrm{C}_{(0)}$ - initial concentration of NAs and TOC; $\mathrm{C}_{(\mathrm{t})}$ - concentration of NAs or TOC at time $\mathrm{t}$.

Description of the kinetic reaction and activated energy $E_{a}$ of the TET, HMX and RDX oxidation using three AOPs was determined based on the concentration of Nitramines $\left(\mathrm{C}_{\mathrm{NAs}}\right)$ and reaction time. The pseudo-first-order rate equation could be used:

$$
\ln \mathrm{C}_{(\mathrm{t}) \mathrm{NAs}} / \mathrm{C}_{(0) \mathrm{NAs}}=\mathrm{k}_{(0) \mathrm{NAs}} \cdot \mathrm{t}
$$

where: $\mathrm{C}_{\mathrm{NAs}(0)}$ and $\mathrm{C}_{\mathrm{NAs}}$ - the concentrations of nitramine compounds at initial time and at time instant $\mathrm{t}$; $\mathrm{k}_{0(\mathrm{NAs})}$-the pseudo-first-order rate constant. 
The activation energy of the reaction was performed by Arrhenius equation Eq. (6) (Bose, Glaze and Maddox, 1998) as follows:

$$
\mathrm{k}_{(0) \mathrm{NAs}}=\mathrm{A} \exp (-\mathrm{Ea} / \mathrm{RT})
$$

where: A-pre-exponential factor; $\mathrm{Ea}$-activation energy; $\mathrm{R}$ - gas constant; $\mathrm{T}$ - temperature.

\section{Energy consumption and current efficiency}

The energy consumption performance per order for the three AOPs can be determined by equation Eq. (7) (Asaithambi, Saravanathamizhan and Matheswaran, 2015).

$$
\mathrm{EE} / \mathrm{O}=\left(\mathrm{kWh} \mathrm{m}^{-3} / \text { order }\right)
$$

where: $\mathrm{P}$ is the electrical power input $(\mathrm{kW})$,

$\mathrm{V}$ is the volume of effluent used (L), $\mathrm{k}$-rate constant of first-order kinetics $\left(\mathrm{min}^{-1}\right)$.

\section{RESULTS AND DISCUSSION}

\section{$\mathrm{UV} / \mathrm{H}_{2} \mathrm{O}_{2}$ process: effect of the initial concentration of $\mathrm{H}_{2} \mathrm{O}_{2}$}

The initial dosage of $\mathrm{H}_{2} \mathrm{O}_{2}$ is the essential operation influencing reduction efficiency in the photolysis of $\mathrm{H}_{2} \mathrm{O}_{2}$ (Zuorro et al. 2014). Thus, the effect of three initial concentrations $(7.5,14.5,29$ $\mathrm{mM}$ ) in $\mathrm{UV} / \mathrm{H}_{2} \mathrm{O}_{2}$ after a reaction time of $40 \mathrm{~min}$ was investigated and the results are shown in Figure 2. Low growth at different rate constant values was found with the $\mathrm{UV} / \mathrm{H}_{2} \mathrm{O}_{2}$ processes with a rise in $\mathrm{H}_{2} \mathrm{O}_{2}$ dosage. The highest reaction constant (k value) for TET, RDX and HMX degradation in the $\mathrm{UV} / \mathrm{H}_{2} \mathrm{O}_{2}$ process was $0.07778,0.03721$ and $0.03786 \mathrm{~min}^{-1}$, respectively. The main effect of the $\mathrm{UV} / \mathrm{H}_{2} \mathrm{O}_{2}$ system was to generate $\mathrm{HO}^{*}$ involved in the oxidation of NAs, determined by Eq. (8). Moreover, apart from the main effect of $\mathrm{HO}^{*}$, it is necessary to take into account the simultaneous effects of UV radiation even though direct quantum photonic activity is not high. The influence of UV makes bonds in the NA molecule weaker and more flexible, and therefore more susceptible to attack by free radicals $\mathrm{HO}^{*}$.

\section{EO/UV/ $\mathrm{H}_{2} \mathrm{O}_{2}$ process: effect of the initial concentration of $\mathrm{H}_{2} \mathrm{O}_{2}$}

As shown in Figure 3, for EO/UV/ $\mathrm{H}_{2} \mathrm{O}_{2}$ processes, a faster increase in the rate constant was found when the initial dose of $\mathrm{H}_{2} \mathrm{O}_{2}$ increased from $7.5 \mathrm{mM}$ to $14.5 \mathrm{mM}$. The rate constant increased from $0.06031 \mathrm{~min}^{-1}$ to $0.08674 \mathrm{~min}^{-1}$, $0.0914 \mathrm{~min}^{-1}$, to $0.1475 \mathrm{~min}^{-1}$, and $0.12577 \mathrm{~min}^{-1}$ to $0.16599 \mathrm{~min}^{-1}$ for HMX, RDX and TET removal, respectively. This is perhaps due to the greater generation of free radicals, such as $\mathrm{OH}^{*}$ and $\mathrm{Cl}^{*}$, by the electrochemical system. Firstly, HO* was produced by water oxidation and physically adsorbed at the anode surface, via the reaction in Eq.(9) (Alfonso-Muniozguren et al. 2020). Furthermore, in EO/UV/ $/ \mathrm{H}_{2} \mathrm{O}_{2}$, hypochlorous acid $(\mathrm{HClO})$ is produced from the oxidation of chloride $\left(\mathrm{Cl}^{-}\right)$, which is included in the effluent of 3 $\mathrm{mg} / \mathrm{L}$ at the anode via the reactions in Eq. (12-14) at pH 6 (Panizza and Cerisola, 2009).

$$
\begin{gathered}
\mathrm{H}_{2} \mathrm{O}_{2}+\mathrm{hv} \rightarrow 2 \mathrm{HO}^{*} \\
\text { Anode }+\mathrm{H}_{2} \mathrm{O} \rightarrow \text { Anode }\left(\mathrm{HO}^{*}\right)+\mathrm{H}^{+}+\mathrm{e}^{-} \\
\mathrm{H}_{2} \mathrm{O}_{2}+\mathrm{HO}^{*} \rightarrow \mathrm{H}_{2} \mathrm{O}+\mathrm{HO}_{2}^{*} \\
\mathrm{HO}^{*}+\mathrm{HO}^{*} \rightarrow \mathrm{H}_{2} \mathrm{O}_{2} \\
2 \mathrm{Cl}^{-} \rightarrow \mathrm{Cl}_{2}+2 \mathrm{e}^{-} \\
\mathrm{Cl}_{2}+\mathrm{H}_{2} \mathrm{O} \rightarrow \mathrm{HClO}^{-} \mathrm{Cl}^{-}+\mathrm{H}^{+} \\
\mathrm{HClO}+\mathrm{hv} \rightarrow \mathrm{HO}^{*}+\mathrm{Cl}^{*}
\end{gathered}
$$

Moreover, an increase in the dosage of $\mathrm{H}_{2} \mathrm{O}_{2}$ to $29 \mathrm{mM}$ led to a decrease in the reaction rate. The reason is that the accumulation of $\mathrm{HO}^{*}$ as well as the reaction of hydroxyl radicals with $\mathrm{H}_{2} \mathrm{O}_{2}$ provide the hydroxyl radical scavenging, following Eq. $(10,11)$. These results show that the optimal initial $\mathrm{H}_{2} \mathrm{O}_{2}$ concentration is $14.5 \mathrm{mM}$. At this concentration, complete degradation of TET was reached after only $20 \mathrm{~min}$, and for RDX at 25 min. Simultaneously, the maximum removal of HMX concentration of $89.85 \%$ was observed in the $\mathrm{EO} / \mathrm{UV} / \mathrm{H}_{2} \mathrm{O}_{2}$ process, with an initial dose of $\mathrm{H}_{2} \mathrm{O}_{2} 14.5 \mathrm{mM}$.

\section{Photo-Fenton process: influence of the ratio $\mathrm{H}_{2} \mathrm{O}_{2} / \mathrm{Fe}^{2+}$ on removal of $\mathrm{NAs}$}

The generation of $\mathrm{HO}^{*}$ includes a different stage in the photo-Fenton system: the primary stage being the photo-Fenton reaction (Eq. (1)), photolysis of $\mathrm{Fe}^{2+}$ (catalyst), and photolysis of $\mathrm{H}_{2} \mathrm{O}_{2}$. Thus, the ratio $\mathrm{H}_{2} \mathrm{O}_{2} / \mathrm{Fe}^{2+}$ constitutes the main condition of this system. As shown in Figure 4, NAs reduction efficiency and the reaction rate constant $(\mathrm{k})$ increased, with an increase in the ratio of $\mathrm{H}_{2} \mathrm{O}_{2} / \mathrm{Fe}^{2+}$; the ratio $\mathrm{H}_{2} \mathrm{O}_{2} /$ $\mathrm{Fe}^{2+}$ increased from $3.65 / 0.34(\mathrm{~m} / \mathrm{m})$ to $29 / 0.624$ $(\mathrm{m} / \mathrm{m})$, constant $\mathrm{k}$ value increased from 0.02158 $\mathrm{min}^{-1}$ to $0.09336 \mathrm{~min}^{-1}$ for HMX removal; from 

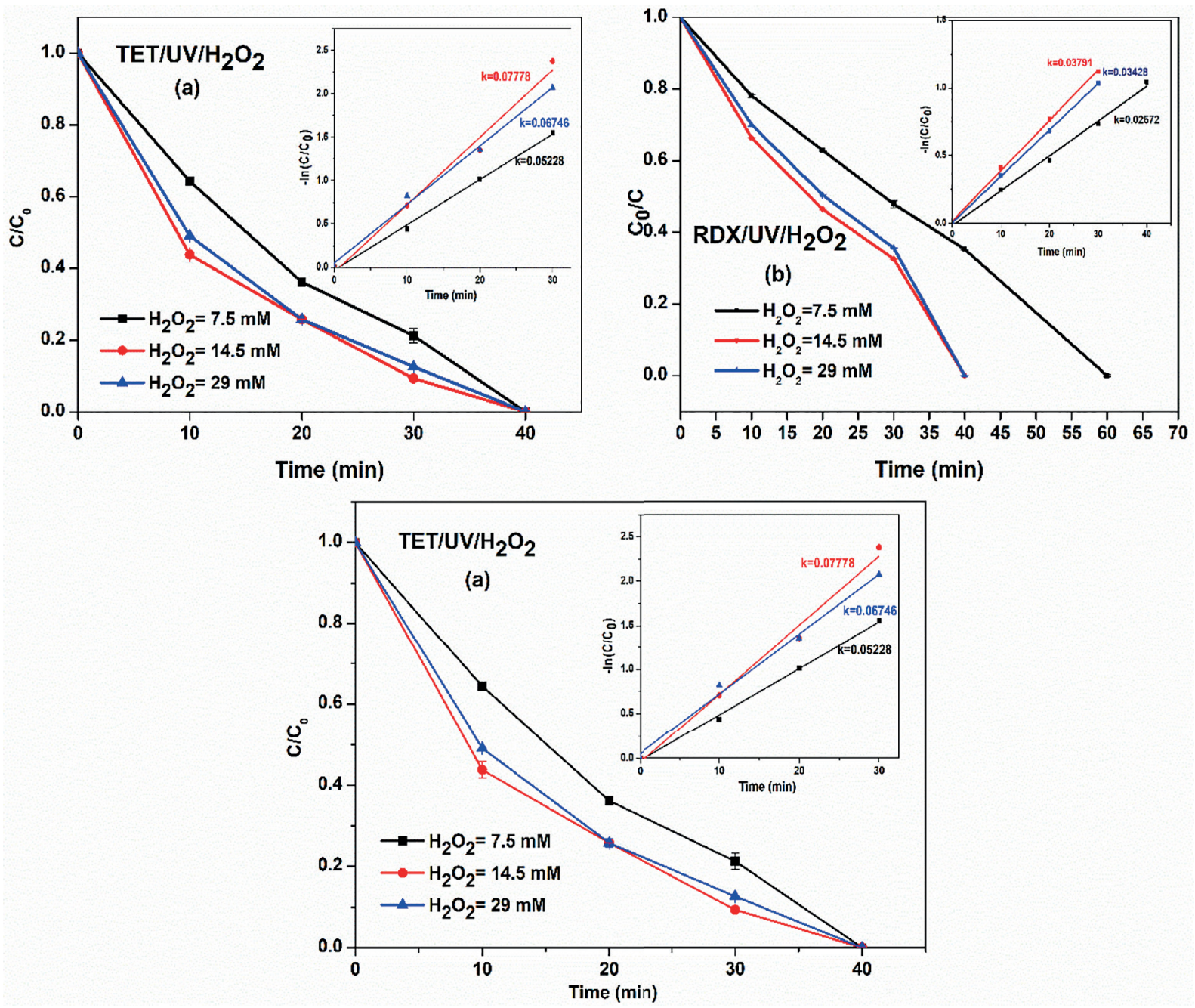

Fig. 2. Effect of $\mathrm{H}_{2} \mathrm{O}_{2}$ concentration on degradation of $\mathrm{NAs}$ in aqueous solution by $\mathrm{UV} / \mathrm{H}_{2} \mathrm{O}_{2}$ process: (a) TET, (b) RDX and (c) TET in system $\mathrm{T}=25^{\circ} \mathrm{C}, \mathrm{I}=875 \mathrm{Lux}, \mathrm{pH}=6$, [TET] $=38.46$ $\mathrm{mg} \mathrm{L}^{-1},[\mathrm{RDX}]=19.22 \mathrm{mg} \mathrm{L}^{-1},[\mathrm{HMX}]=5.28 \mathrm{mg} \mathrm{L}^{-1}$. (inset: $\ln \left(\mathrm{C}_{\mathrm{C}} \mathrm{C}_{\mathrm{o}}\right)$ vs reaction time)

0.07004 to $0.1501 \mathrm{~min}^{-1} \mathrm{RDX}$ reduction; and 0.12331 to $0.17882 \mathrm{~min}^{-1}$ for TET degradation. Conversely, a further increase in the $\mathrm{H}_{2} \mathrm{O}_{2} / \mathrm{Fe}^{2+}$ ratio to $29 / 1.35(\mathrm{~m} / \mathrm{m})$, produced lower HMX, RDX, and TET removal efficiency improvements ( $\mathrm{k}$ values) at $0.17522,0.12818$ and 0.0834 $\mathrm{min}^{-1}$, respectively. This was due to the scavenger effect of excess $\mathrm{Fe}^{2+}$, where $\mathrm{HO}^{*}$ reacts with redundant ferrous iron, as shown in Eq. (15). The optimal ratio of $\mathrm{H}_{2} \mathrm{O}_{2} / \mathrm{Fe}^{2+}$ for the photoFenton reaction was observed at 29/0.624. In comparison, the traditional photo-Fenton process in acidic condition consumes less $\mathrm{H}_{2} \mathrm{O}_{2}$ and requires only catalytic amounts of $\mathrm{Fe}^{2+}$; this study recommends a relatively higher $\mathrm{H}_{2} \mathrm{O}_{2}$ concentration and lower catalyst $\left(\mathrm{Fe}^{2+}\right)$. This may explain the photo-Fenton activation mechanism in near neutral $(\mathrm{pH}=6)$ conditions, which exist in a photo-congestion region, requiring definition of the participation of precipitated iron. First, in the photo-Fenton system, soluble iron ion $\left(\mathrm{Fe}^{2+}\right)$ is observed as iron hydroxides at near-neutral $\mathrm{pH}(\mathrm{pH}=6)\left(\right.$ Eq. 16). After that, $\mathrm{Fe}_{(\mathrm{s})}{ }^{3+}$ can be reduced to $\mathrm{Fe}^{2+}$ sy UV light in the solid phase by Eq. 17. Finally, $\mathrm{Fe}^{2+}{ }_{\mathrm{s}}$ can be reoxidized to $\mathrm{Fe}^{3+}{ }_{\mathrm{s}}$ by $\mathrm{H}_{2} \mathrm{O}_{2}$ (Eq. 16), which controls this process, and photo saturation occurs (Casado et al.2021). The $\mathrm{Fe}^{3+}{ }_{\mathrm{s}}$ absorbs photons much more than $\mathrm{H}_{2} \mathrm{O}_{2}$ at a wavelength of $254 \mathrm{~nm}$, so the photosynthetic reaction in Eq. 17 is much greater than the $\mathrm{H}_{2} \mathrm{O}_{2}$ photosynthetic formation of hydroxyl radicals. This is also the reason why the efficiency of NA reduction with the photo-Fenton process is greater than that of the $\mathrm{UV} / \mathrm{H}_{2} \mathrm{O}_{2}$ and $\mathrm{EO} / \mathrm{UV} /$ $\mathrm{H}_{2} \mathrm{O}_{2}$ systems (data shown in Table 3).

$$
\begin{gathered}
\mathrm{Fe}^{2+}+\mathrm{HO}^{*} \rightarrow \mathrm{Fe}^{3+}+\mathrm{OH}^{-} \\
\mathrm{Fe}^{2+}+\mathrm{H}_{2} \mathrm{O}_{2} \rightarrow \mathrm{Fe}^{3+}+\mathrm{HO}^{*} \mathrm{k}=19.95 \mathrm{M}^{-1} \mathrm{~s}^{-1}
\end{gathered}
$$



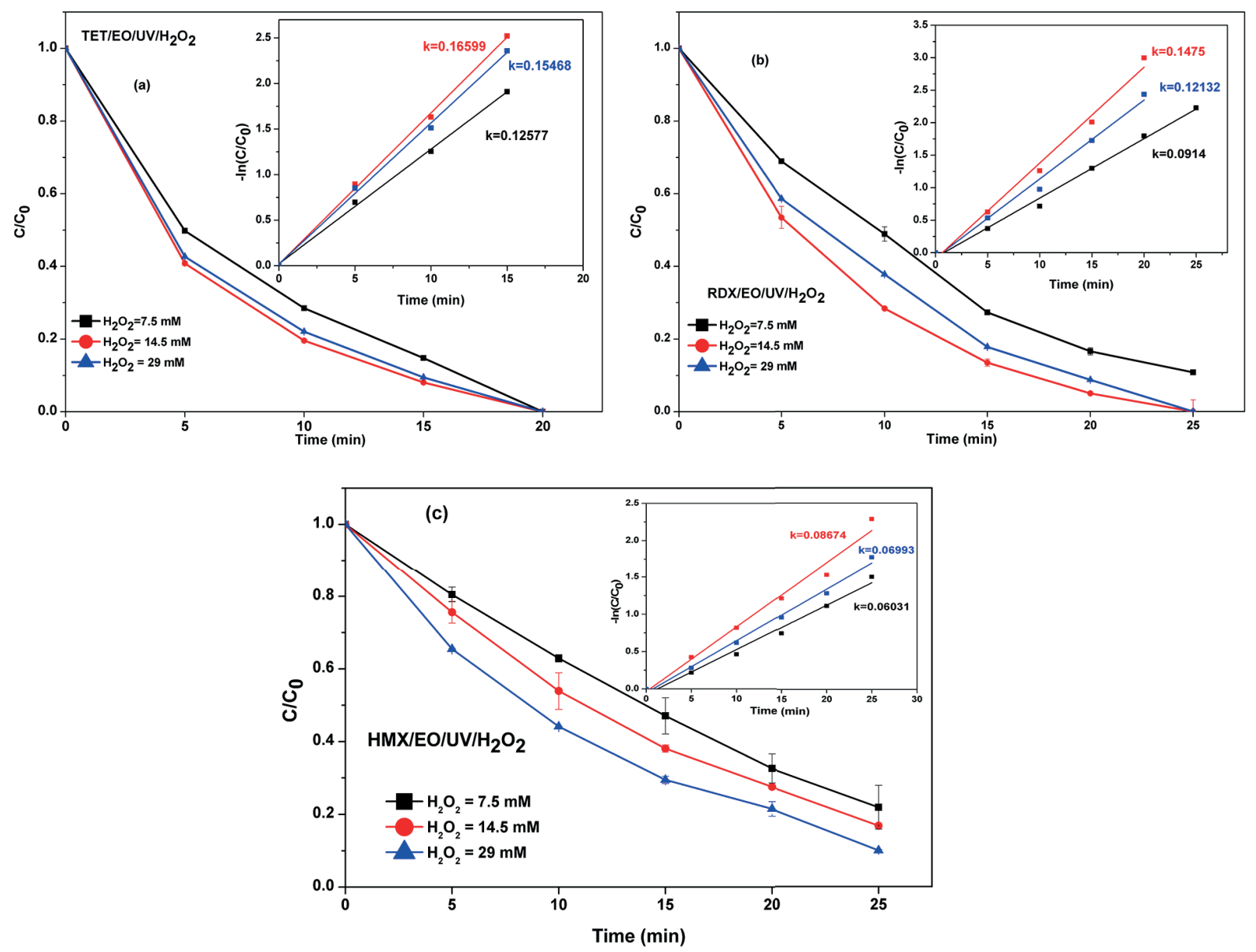

Fig. 3. Effect of $\mathrm{H}_{2} \mathrm{O}_{2}$ concentration on degradation of $\mathrm{NAs}$ in aqueous solution by EO/UV/ $\mathrm{H}_{2} \mathrm{O}_{2}$ process: (a) TET, (b) RDX and (c) TET in system $\mathrm{TiO}_{2} / \mathrm{Inox}, \mathrm{I}=1 \mathrm{~A} \mathrm{dm}^{-2}, \mathrm{NaCl}=3 \mathrm{~g} \mathrm{~L}^{-1}, \mathrm{~T}=25^{\circ} \mathrm{C}, \mathrm{I}=875 \mathrm{Lux}, \mathrm{pH}=6$,

$[\mathrm{TET}]=38.46 \mathrm{mg} \mathrm{L}^{-1},[\mathrm{RDX}]=19.22 \mathrm{mg} \mathrm{L}^{-1},[\mathrm{HMX}]=5.28 \mathrm{mg} \mathrm{L}^{-1}$. (inset: $\ln \left(\mathrm{C} / \mathrm{C}_{\mathrm{o}}\right)$ vs reaction time)

$$
\begin{gathered}
\mathrm{Fe}^{3+}+\mathrm{H}_{2} \mathrm{O}+h v \rightarrow \mathrm{Fe}^{+2}{ }_{(\mathrm{s})}+ \\
+\mathrm{HO}^{*}+\mathrm{H}^{+} \mathrm{k}=3.92 \times 10^{-5} \mathrm{M}^{-1} \mathrm{~s}^{-1} \\
\mathrm{Fe}^{2+}{ }_{(\mathrm{s})}+\mathrm{H}_{2} \mathrm{O}_{2} \rightarrow \mathrm{Fe}^{3+}{ }_{(\mathrm{s})}^{+(}+ \\
+\mathrm{HO}^{*}+\mathrm{H}^{+} \mathrm{k}=7.66 \mathrm{M}^{-1} \mathrm{~s}^{-1}
\end{gathered}
$$

\section{Effect of temperature on the removal of NAs by $\mathrm{UV} / \mathrm{H}_{2} \mathrm{O}_{2}, \mathrm{EO} / \mathrm{UV} / \mathrm{H}_{2} \mathrm{O}_{2}$, and photo-Fenton}

The reaction temperature is a critical condition. Figure 5 illustrates the influence of the reaction temperature on NA removal using the three AOPs: $\mathrm{UV} / \mathrm{H}_{2} \mathrm{O}_{2}, \mathrm{EO} / \mathrm{UV} / \mathrm{H}_{2} \mathrm{O}_{2}$, and photo-Fenton. Experiments were conducted at various temperatures: $20^{\circ} \mathrm{C}, 25^{\circ} \mathrm{C}, 30^{\circ} \mathrm{C}, 35^{\circ} \mathrm{C}$, and $40^{\circ} \mathrm{C}$. It can be observed that by raising the temperature, the rate of reaction increases significantly for all three AOPs processes. For example, the reaction rate constant for HMX removal in $\mathrm{UV} / \mathrm{H}_{2} \mathrm{O}_{2}$ increases from 0.0065 $\min ^{-1}$ to $0.098 \mathrm{~min}^{-1}$ by raising the temperature from $20^{\circ} \mathrm{C}$ to $40^{\circ} \mathrm{C}$. Similarly, the k value of $\mathrm{RDX}$ reduction by $\mathrm{EO} / \mathrm{UV} / \mathrm{H}_{2} \mathrm{O}_{2}$ increases from $0.0067 \mathrm{~min}^{-1}$ to $0.2393 \mathrm{~min}^{-1}$. In the degradation of TET by the photo-Fenton system, the highest $\mathrm{k}$ value is $0.2833 \mathrm{~min}^{-1}$ at $40{ }^{\circ} \mathrm{C}$. Further increasing temperature, these are complete removal for NAs with electron-hole recombination due to free radical production increase (Ali et al. 2019).

The activation energy Ea values for NAs reduction by the $\mathrm{UV} / \mathrm{H}_{2} \mathrm{O}_{2}, \mathrm{EO} / \mathrm{UV} / \mathrm{H}_{2} \mathrm{O}_{2}$ and photo-Fenton system were calculated (Table $2)$. It can be concluded that TET degradation by the three AOPs is the most efficient, which can be explained by the structure of TET, which is a compound containing aromatic rings with less chemical resistance than RDX and HMX. The electronic substitute group of aromatic compounds often depends on the group's tendency to attract or repel electrons. Electronic repelling groups, such as $-\mathrm{CH}_{3},-\mathrm{NH}_{2}$ and $-\mathrm{OH}$, activate the aromatic ring, while the electronic attracting groups, such as $-\mathrm{NO}_{2},-\mathrm{COOH},-\mathrm{NH}_{3}$ 

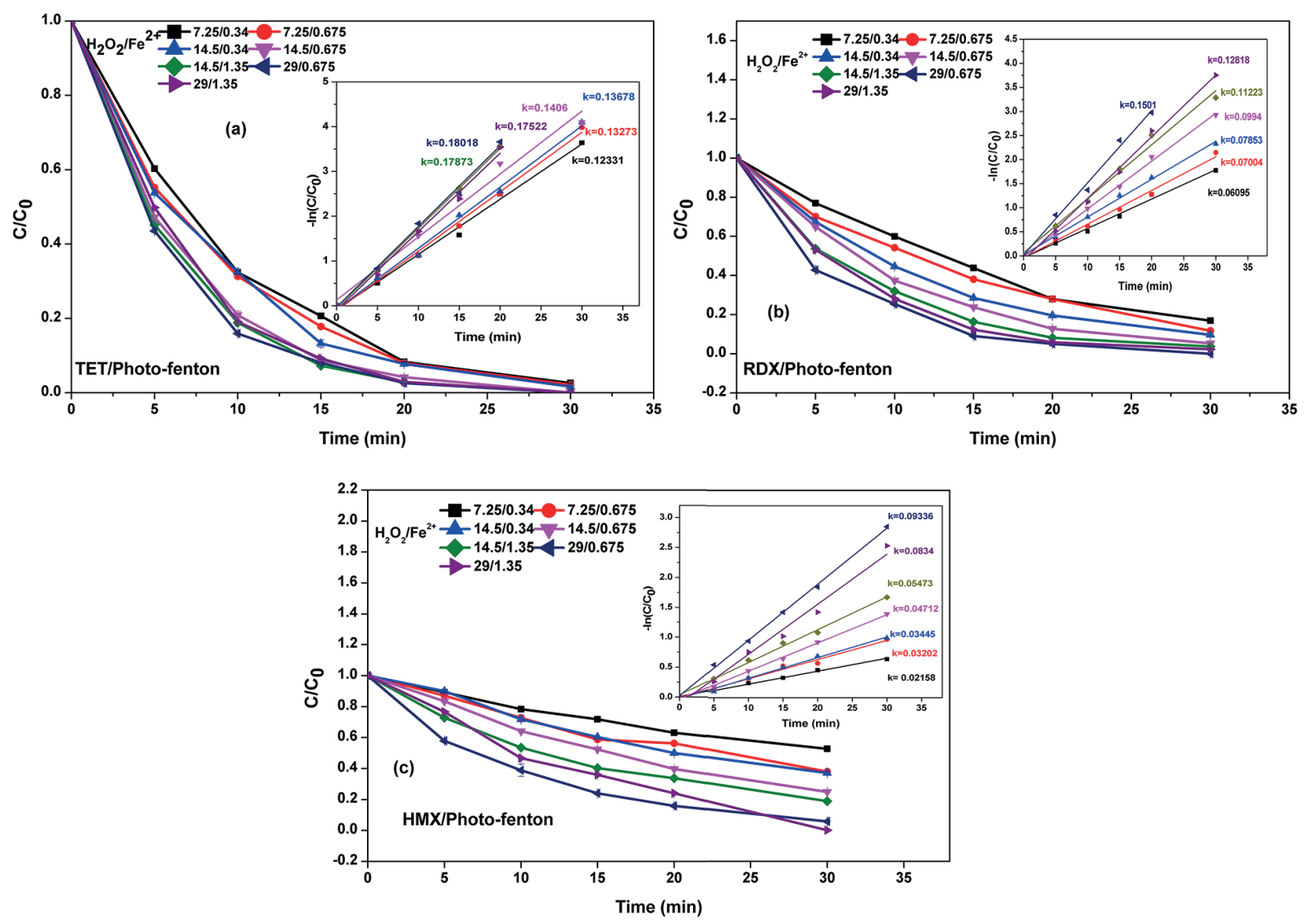

Fig. 4. Effect of ratio $\mathrm{H}_{2} \mathrm{O}_{2} / \mathrm{Fe}^{2+}$ on degradation of NAs by photo-Fenton process: (a)TET, (b) RDX and (c) TET; inset kinetic of NAs degradation in photo-Fenton process in condition $\mathrm{T}=25^{\circ} \mathrm{C}, \mathrm{I}=875 \mathrm{Lux}, \mathrm{pH}=6$,

$[\mathrm{TET}]=38.46 \mathrm{mg} \mathrm{L}^{-1},[\mathrm{RDX}]=19.22 \mathrm{mg}^{-1} \mathrm{~L},[\mathrm{HMX}]=5.28 \mathrm{mg} \mathrm{L}^{-1}$. (inset: $\ln \left(\mathrm{C} / \mathrm{C}_{\mathrm{o}}\right)$ vs reaction time)

and $-\mathrm{CN}$, reactivate the aromatic ring. The nitramine ring compounds RDX and HMX do not have the same electronic state as the benzene rings of aromatic nitro compounds, or of TET; therefore, even in the three AOPs processes, the efficiency of TET reduction is significantly higher.

It is observed that the internal bond angle of HMX is much greater than that of RDX, and so it is easier to oxidize RDX than HMX. Consequently, the degradation potential determined by comparing the molecule structure and orbital hydride is in line with the experimental results of Liou et al. (2003).

\section{Comparison of the three AOPs processes}

\section{Efficiency of NA removal}

All the reactions follow the pseudo-first-order kinetic model. Rate constant $\mathrm{k}$ reactions were calculated from the linear regression Eq. (5) with R2 higher than 0.98 , as reported in Table 3 . NAs removal from aqueous solutions by the three AOPs was observed in descending order as follows: $\mathrm{UV} / \mathrm{H}_{2} \mathrm{O}_{2}<\mathrm{EO} / \mathrm{UV} / \mathrm{H}_{2} \mathrm{O}_{2}<$ photo-Fenton. For example, TET was degraded by $\mathrm{UV} / \mathrm{H}_{2} \mathrm{O}_{2}, \mathrm{EO} /$ $\mathrm{UV} / \mathrm{H}_{2} \mathrm{O}_{2}$, and photo-Fenton processes at nearneutral $\mathrm{pH}$ at $\mathrm{k}$ values of $0.0778,0.016599$ and $0.18018 \mathrm{~min}^{-1}$, respectively. While for RDX degradation, $0.3791,0.1475$ and $0.1501 \mathrm{~min}^{-1}$ were

Table 2. The activation energy for NAs degradation by NAs/UV- $\mathrm{H}_{2} \mathrm{O}_{2}, \mathrm{NAs} / \mathrm{EO} / \mathrm{UV} / \mathrm{H}_{2} \mathrm{O}_{2}$ and NAs/photo-Fenton systems

\begin{tabular}{|c|c|c|c|}
\hline Specification & $\begin{array}{c}\mathrm{UV} / \mathrm{H}_{2} \mathrm{O}_{2} \\
\mathrm{E}_{\mathrm{a}}, \mathrm{kJ} / \mathrm{mol}\end{array}$ & $\begin{array}{c}\mathrm{EO} / \mathrm{UV}^{\mathrm{H}} \mathrm{H}_{2} \mathrm{O}_{2} \\
\mathrm{E}_{\mathrm{a}}, \mathrm{kJ} / \mathrm{mol}^{2}\end{array}$ & $\begin{array}{c}\text { Photo }- \text { Fenton } \\
\mathrm{E}_{\mathrm{a}}, \mathrm{kJ} / \mathrm{mol}\end{array}$ \\
\hline $\mathrm{TET}$ & 43.981 & 18.56 & 27.53 \\
\hline $\mathrm{RDX}$ & 61.906 & 34.78 & 40.33 \\
\hline $\mathrm{HMX}$ & 72.257 & 36.86 & 49.56 \\
\hline
\end{tabular}



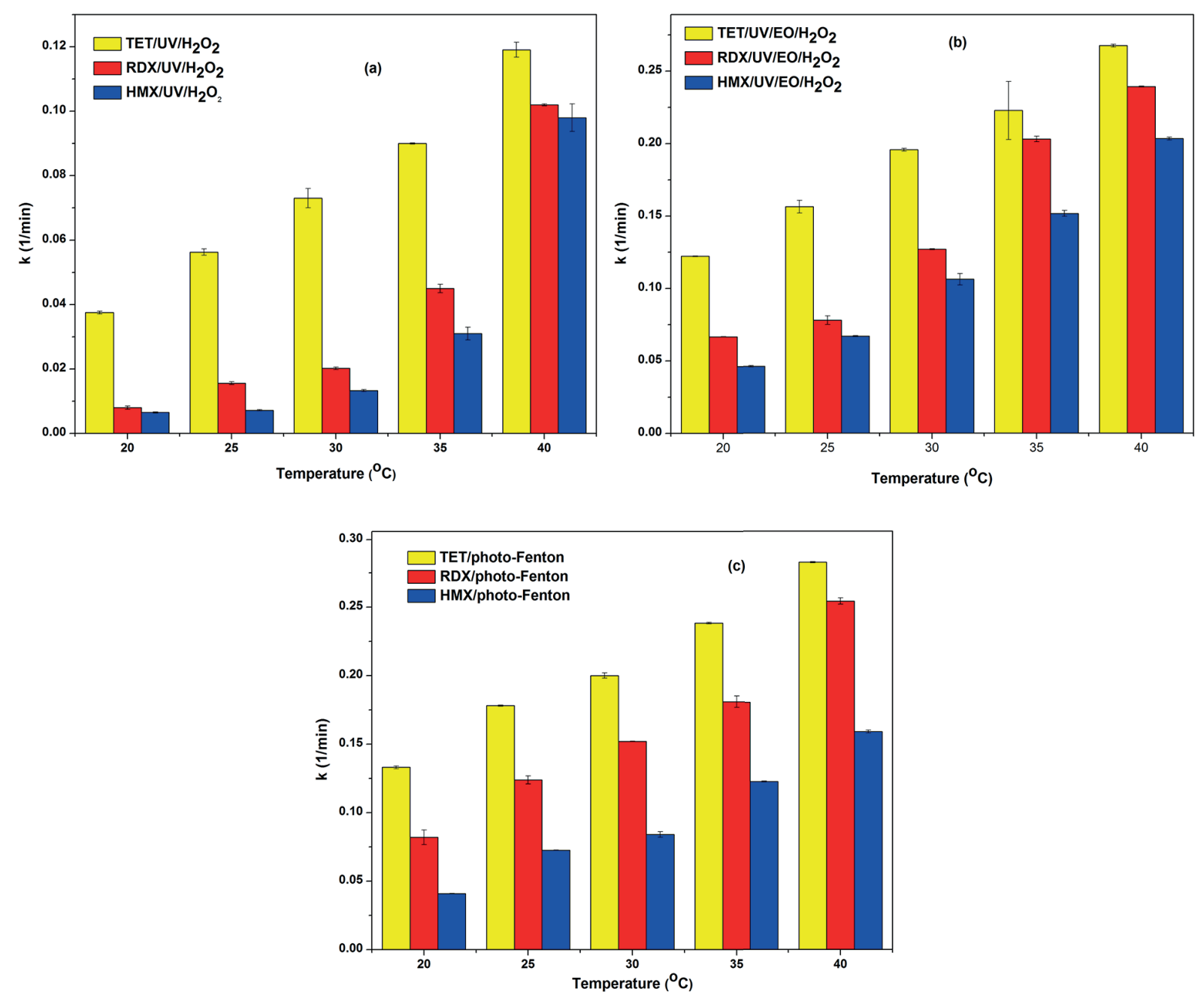

Fig. 5. Influence of temperature on NAs degradation for (a) $\mathrm{UV} / \mathrm{H}_{2} \mathrm{O}_{2}$, (b) $\mathrm{EO} / \mathrm{UV} / \mathrm{H}_{2} \mathrm{O}_{2}$, and (c) photo-Fenton in system $\mathrm{I}=875 \mathrm{Lux}, \mathrm{pH}=6,[\mathrm{TET}]=38.46 \mathrm{mg} \mathrm{L}^{-1},[\mathrm{RDX}]=19.22 \mathrm{mg} \mathrm{L}^{-1}$, [HMX] $5.28 \mathrm{mg} \mathrm{L}^{-1},\left[\mathrm{H}_{2} \mathrm{O}_{2}\right]=14.5 \mathrm{mM}$ for $(\mathrm{a}),(\mathrm{b})$ and ratio concentration of $\mathrm{H}_{2} \mathrm{O}_{2} / \mathrm{Fe}^{2+}=29 / 0.624$.

illustrated for $\mathrm{UV} / \mathrm{H}_{2} \mathrm{O}_{2}$, electrochemical oxidation, and photo-Fenton. Regarding kinetic constants, the photo-Fenton process was 2.3 times and 1.1 times faster than the $\mathrm{EO} / \mathrm{UV} / \mathrm{H}_{2} \mathrm{O}_{2}$ and $\mathrm{UV} / \mathrm{H}_{2} \mathrm{O}_{2}$ process for NAs oxidation in circumneutral conditions, respectively. These results were predictable, and it is consistent with previous studies. Liou et al. (2003) reported that TNP, AP, 2,4-DNT, TET, 2,4,6-TNT, RDX and HMX were degraded significantly with UV light in the photo-Fenton system.

With the same process treatment, the values of TET, RDX and HMX were different, in some cases even of one order of magnitude of difference. Considering the reactions with $\mathrm{HO}^{*}$ radical are indiscriminate and it is also highly reactive with organics hence there no distinction about $\mathrm{k}$. In term of the wayward feature of both contaminants, their similar structure does not have any big difference. In the real water effluent, the large difference about the concentration of TET (38.46 mg L-1), RDX (19.22 $\mathrm{mg} \mathrm{L}^{-1}$ ) and HMX (5.28 mg $\left.\mathrm{L}^{-1}\right)$ since the variation of $k$ values. It is necessary to consider that $\mathrm{HO}^{*}$ radical is vying exhausted by the several of organics in solution, even though there is the pseudo-first order kinetics non self-reliant to the original concentration. As the results, these toxic waste in higher concentration will be privileged degraded.

\section{Electrical energy consumption}

The electrical energy consumption of the three AOPs system is shown in Table 3. It can be seen that higher electrical energy consumption corresponds to lower efficiency of NA removal. From the research, the lowest energy consumption for the greatest pollutant removal is the photo-Fenton process. Thus, with the photo-Fenton process and a rate constant of $0.18018,0.1501$ and 0.09336 
Table 3. Comparison of three AOPs processes on NAs removal

\begin{tabular}{|c|c|c|c|}
\hline AOPs process & Specification & $\begin{array}{c}\text { Kinetic rate constant } \\
k(1 / \mathrm{min})\end{array}$ & $\begin{array}{c}\text { Electrical energy determination } \\
\left(\mathrm{kWh} / \mathrm{m}^{3} \text { order }\right)\end{array}$ \\
\hline \multirow{3}{*}{$\mathrm{UV} / \mathrm{H}_{2} \mathrm{O}_{2}$} & $\mathrm{TET} / \mathrm{UV} / \mathrm{H}_{2} \mathrm{O}_{2}$ & 0.07778 & 14.811 \\
\cline { 2 - 4 } & $\mathrm{RDX} / \mathrm{UV} / \mathrm{H}_{2} \mathrm{O}_{2}$ & 0.03791 & 30.388 \\
\cline { 2 - 4 } & $\mathrm{HMX} / \mathrm{UV} / \mathrm{H}_{2} \mathrm{O}_{2}$ & 0.03786 & 30.428 \\
\hline \multirow{3}{*}{$E \mathrm{EO} / \mathrm{UV} / \mathrm{H}_{2} \mathrm{O}_{2}$} & $\mathrm{TET} / \mathrm{EO} / \mathrm{UV} / \mathrm{H}_{2} \mathrm{O}_{2}$ & 0.16599 & 12.492 \\
\cline { 2 - 4 } & $\mathrm{RDX} / \mathrm{EO} / \mathrm{UV} / \mathrm{H}_{2} \mathrm{O}_{2}$ & 0.14750 & 14.058 \\
\cline { 2 - 4 } & $\mathrm{HMX/EO} / \mathrm{UV} / \mathrm{H}_{2} \mathrm{O}_{2}$ & 0.08674 & 23.906 \\
\hline
\end{tabular}

$\min ^{-1}$, with $\mathrm{pH}=6,15 \mathrm{~W}$ light source, and $0.5 \mathrm{~L}$ of treated TET, RDX and HMX solution, the EEC is calculated as 2.132, 2.558 and $4.113 \mathrm{kWh} \mathrm{m}^{-3}$, respectively. In this condition, considering its price in the Vietnamese market $\left(0.11{\mathrm{US} \$ \mathrm{kWh}^{-1}}^{-1}\right.$ in 2020), the electrical energy cost will be 0.235 ,

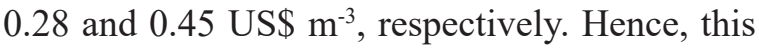
process can be applied for the treatment of NA explosives in water.

\section{Mineralization and toxicity evaluation on $N A$ degradation of photo-Fenton at $\mathrm{pH}=6$}

It is true that mineralization is a complete degradation of organics and relevant by-products to $\mathrm{CO}_{2}, \mathrm{H}_{2} \mathrm{O}$, and other mineral oxides. In-situ mineralization of organic pollutants is a crucial advantages of AOPs compared with physical and biological methods. This test was shown on treated NA solution (by photo-Fenton under optimum conditions). Figure 6 determines that the photoFenton process at $\mathrm{pH}=6$ is able to mineralize TET, RDX and HMX solutions, by around 59.7\%, $45.1 \%$ and $25.8 \%$, respectively, after $60 \mathrm{~min}$.

Following Drzyzga et al. (1995), the $\mathrm{EC}_{50}$ after 30 min for TET, RDX, and HMX with $V$. fischeri were determined to be $0.45 \mathrm{mg} \mathrm{L}^{-1}, 74.56 \mathrm{mg}$ $\mathrm{L}^{-1}$, and $25 \mathrm{mg} \mathrm{L}^{-1}$, respectively. The toxicities for $V$. fischeri of NAs were investigated during the photo-Fenton process (Fig. 7). The inhibition ratio of TET was highest: $100 \%$ for the control sample $\left(\mathrm{TET}=38.46 \mathrm{mg} \mathrm{L}^{-1}\right)$, then dropped significantly with increasing reaction time of the photo-Fenton process. After 30 and $60 \mathrm{~min}$, no toxicity was observed. This result indicated that the toxicity for $V$. fischeri was attributed to decreasing TET concentration and the transformation products of TET becoming less toxic than TET itself. Similar results were observed for photo-Fenton treatment at $\mathrm{pH}=6$ of $\mathrm{RDX}$ and HMX using the luminescent bacteria test ( $V$. fischeri). The acute test with $V$. fischeri showed no sensitivity to the after 30-min

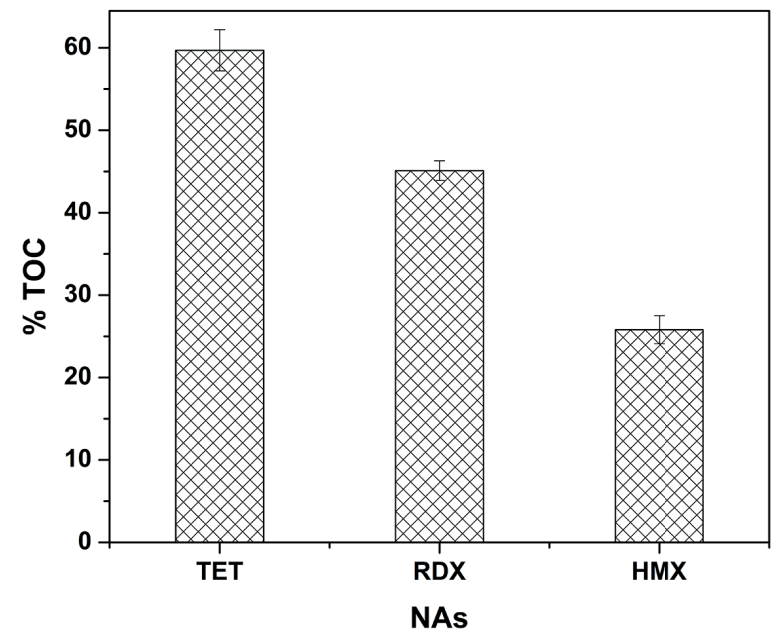

Fig. 6. Total organic carbon (TOC) concentration of NAs after 60 min photo-Fenton degradation in experiment condition, $\mathrm{pH}=6$, [TET] $=38.46$ $\mathrm{mg} / \mathrm{L},[\mathrm{RDX}]=19.22 \mathrm{mg} \mathrm{L}^{-1},[\mathrm{HMX}]=5.28 \mathrm{mg}$

$\mathrm{L}^{-1}$ and ratio $\mathrm{H}_{2} \mathrm{O}_{2} / \mathrm{Fe}^{2+}=29 / 0.624(\mathrm{~m} / \mathrm{m})$

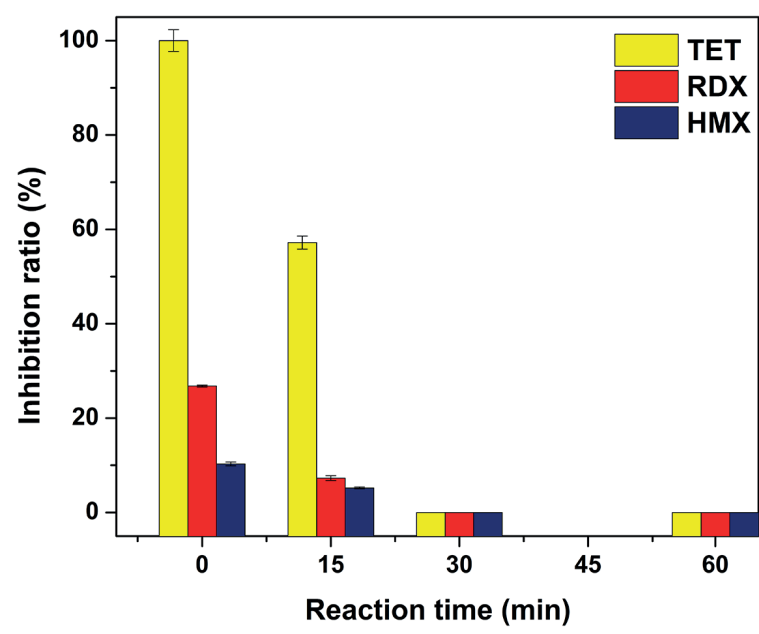

Fig. 7. Inhibition ratio of $V$. fischeri under initial (a) TET, (b) RDX, and (c) HMX concentration at each photo-Fenton reaction time (0-60 $\mathrm{min})$ in experiment condition, $\mathrm{pH}=6$, $[\mathrm{TET}]=38.46$ $\mathrm{mg} / \mathrm{L},[\mathrm{RDX}]=19.22 \mathrm{mg} / \mathrm{L},[\mathrm{HMX}]=5.28$ $\mathrm{mg} / \mathrm{L}$ and ratio $\mathrm{H}_{2} \mathrm{O}_{2} / \mathrm{Fe}^{2+}=29 / 0.624(\mathrm{~m} / \mathrm{m}$ 
and 60 -min treatment by the photo-Fenton system. Eventhough $V$. fischeri is usually described to be sensitive to organic pollutants in effluent, toxicity occurs in the parts-per-million range concentration (Larsson et al. 2007).

\section{CONCLUSIONS}

The AOPs, assisted with UV light, $\mathrm{UV} / \mathrm{H}_{2} \mathrm{O}_{2}$, $\mathrm{EO} / \mathrm{UV} / \mathrm{H}_{2} \mathrm{O}_{2}$, and photo-Fenton at $\mathrm{pH}=6$, can be used for degradation of TET, RDX and HMX explosives. The removal efficiency and rate constant of a reaction is influenced by the concentration of $\mathrm{H}_{2} \mathrm{O}_{2}$ and by $\mathrm{H}_{2} \mathrm{O}_{2} / \mathrm{Fe}^{2+}$ parameters. From this research, it can be assumed that photo-Fenton has the highest effect on degradation of the three NA explosives. The oxidation rate of the explosives was in the order TET $>$ RDX $>$ HMX. From the kinetic analysis, the reaction of the three systems was found to be first-order. The rate constant values at optimum operating conditions were found to be $0.18018,0.1501$ and $0.09336 \mathrm{~min}^{-1}$ for TET, RDX and HMX reduction, respectively. To the best of our attention, this is the first research of the application of a photo-Fenton process at near-neutral $\mathrm{pH}$ for NAs explosives degradation. This process enables the efficient removal of TET, RDX and HMX compounds, and can be performed economically in respect of electrical energy consumption and cost. At the optimum condition of photo Fenton near neutral after 40 min, consumption was were observed at 12.132 , 2.558 and $4.113 \mathrm{kWhm}^{-3}$, respectively, with costs of $0.235,0.28$, and $0.45 \mathrm{USS}^{-3}$ for TET, RDX and HMX removal, respectively. As shown by mineralization and toxicity with $V$. fischeri, photo-Fenton at circum-neutral $\mathrm{pH}$ has the potential to be applied in practice to treat wastewater.

\section{REFERENCES}

1. Alfonso-Muniozguren, P., Cotillas, S., Boaventura, R.A.R., Moreirac, F.C.,Lee, J., Vilarc, V.J.P. 2020. Single and combined electrochemical oxidation driven processes for the treatment of slaughterhouse wastewater. Journal of Cleaner Production. 270, 121858.

2. Ali, A. S., Nomura, K., Homonnay,Z., Kuzmann,E., Scrimshire, A., Bingham, P.A., Krehula, S., Ristić, M., Musić, S., Kubuki, S. 2019.The relationship between local structure and photo-Fenton catalytic ability of glasses and glass-ceramics prepared from
Japanese slag. Journal of Radioanalytical and Nuclear Chemistry, 322, 751-761.

3. Andreozzi, R, Caprio, V., Insola, A., Marotta R. 1999. Advanced oxidation processes (AOP) for water purification and recovery. Catalysis Today. 53(1), 51-59.

4. Asaithambi, P., Saravanathamizhan, R., Matheswaran, M. 2015. Comparison of treatment and energy efficiency of advanced oxidation processes for the distillery wastewater. International Journal of Environmental Science and Technology. 12, 2213-2220

5. Raju, B., Keerthi, R., Latha, S., Prabhakar, S. 2011. Degradation of dyes by $\mathrm{UV} / \mathrm{O}_{3} / \mathrm{H}_{2} \mathrm{O}_{2}$ and electrooxidation techniques. Water Practice and Technology, 6(1).

6. Bishop, R.L., Harradine, D.M., Flesner, R.L., Larson, S.A., Bell D.A. 2000. Safe operating temperatures for pressurized alkaline hydrolysis of HMX- based explosives. Industrial and Engineering Chemistry Research, 39(5), 1215-1220.

7. Bose, P., Glaze, W.H., Maddox, D.S. 1998. Degradation of RDX by various advanced oxidation processes: I. Reaction rates. Water Research, 32(4), 997-1004.

8. Casado, C., Moreno-SanSegundo, J., Obra J., García, B.E., Pérez, J.A.S., Marugán, J. 2021. Mechanistic modelling of wastewater disinfection by the photo-Fenton process at circumneutral $\mathrm{pH}$. Chemical Engineering Journal. 403(1), 12633

9. Clarizia, L., Russo, D., Somma, I.D., Marotta, R., Andreozzi, R. 2017. Homogeneous photo-Fenton processes at near neutral $\mathrm{pH}$ : A review. Applied Catalysis B: Environmental.209, 358-371

10. Cyplik, P., Marecik,R., Piotrowska-Cyplik,A., Olejnik,A., Drożdżyńska, A, Chrzanowski, L. 2012. Biological Denitrification of High Nitrate Processing Wastewaters from Explosives Production Plant. Water, Air, \& Soil Pollution, 223(4), 1791-1800.

11. Dalvand, A., Gholami,M., Joneidi, A., Mahmoodi, N.M. 2011. Dye Removal, Energy Consumption and Operating Cost of Electrocoagulation of Textile Wastewater as a Clean Process. CLEAN - Soil, Air, Water. 39(7), 665-672.

12. Fallahzadeh, R.A., Mahvi, A.H., Meybodi, M.N., Ghaneian, M.T., Dalvand, A., Salmani, M.H., Fallahzadeh, M., Ehrampoush, M.H. 2019. Application of photo-electro oxidation process for amoxicillin removal from aqueous solution: Modeling and toxicity evaluation. Korean Journal of Chemical Engineering. 36, 713-721.

13. Fiala, E.S. 1977. Investigations into the metabolism and mode of action of the colon carcinogens 1,2-dimethylhydrazine and azoxymethane. Cancer.

14. Freedman, D.L. and Sutherland, K.W. 1998. Biodegradation of hexahydro-1,3,5-trinitro-1,3,5-triazine 
(RDX) under nitrate-reducing conditions. Water Science and Technology, 38(7), 33-40.

15. Hao, O.J. and Phull, K.K. 1993. Wet oxidation of nitrotoluenesulfonic acid: some intermediates, reaction pathways, and byproduct toxicity. Environmental Science \& Technology, 27(8), 1650-1658.

16. International Organization for Standardization 2007. Water quality-Determination of the inhibitory effect of water samples on te light emission of vibrio fischeri (Luminescent bacteria test)- Part 3: Method using freeze-dried bacteria', ISO 11348-3:2007.

17. Khue, D.N., Lam, T.D., Chat, N.V., Bach, V.Q., Minh, D.B., Loi, V.D., Anh, N.V. 2014. Simultaneous degradation of 2,4,6-trinitrophenyl-N-methylnitramine (Tetryl) and hexahydro-1,3,5-trinitro-1,3,5 triazine (RDX) in polluted wastewater using some advanced oxidation processes. Journal of Industrial and Engineering Chemistry. 20(4), 1468-1475.

18. Khue, D.N., Lam, T.D., Minh, D.B., Loi, V.D., Nam, N.H., Bach, N.Q., Anh, N.V., Hoang, N.V., Hung, D.D. 2016. Enhancement of Electron Transfer in Various Photo-Assisted Oxidation Processes for Nitro-Phenolic Compound Conversion. Journal of Electronic Materials, 45(8), 4221-4227.

19. Khue, D.N., Lam, T.D., Hung, D.D., Bach, V.Q., Anh N.V., Nam, N.H., Thai, N.V., Minh, D.B., 2018. Parameters controlling the advanced oxidation degradation kinetics of nitroglycerin and pentaerythritol tetranitrate. Green Processing and Synthesis. 7, 61-67.

20. Larsson, D.G.J., de Pedro, C. and Paxeus, N. 2007. Effluent from drug manufactures contains extremely high levels of pharmaceuticals. Journal of Hazardous Materials. 148(3), 751-755.

21. Lewis-Younger, C.R., Mamalis, N., Egger, M.J, 2000. Lens Opacifications Detected by Slitlamp Biomicroscopy Are Associated With Exposure to Organic Nitrate Explosives. Archives of Ophthalmology. 118(12), 1653-1659.
22. Lingamdinne, L.P. 2015. Influencing factors on sorption of TNT and RDX using rice husk biochar. Journal of Industrial and Engineering Chemistry, $32,178-186$.

23. Liou, M.J., Lu, M.C., Chen, J.N. 2003. Oxidation of explosives by Fenton and photo-Fenton processes. Water Research, 37(13), 3172-3179.

24. De Luca, A., Dantas, R.F., Esplugas, S. 2014. Assessment of iron chelates efficiency forphoto-Fenton at neutral pH. Water Research, 61(15), 232-242.

25. Martínez-Huitle, C.A., Santos, E.V., Araújo, D.M., Panizza, M. 2012. Applicability of diamond electrode/anode to the electrochemical treatment of a real textile effluent. Journal of Electroanalytical Chemistry. 674, 103-107.

26. Odetola, C., Trevani, L.N., Easton, E.B. 2017 .Photo enhanced methanol electrooxidation: Further insights into $\mathrm{Pt}$ and $\mathrm{TiO}_{2}$ nanoparticle contributions. Applied Catalysis B: Environmental. 210, 263-275.

27. Radovic, M., Mitrović Jelena Z., Kostić Miloš M., Bojić Danijela V., Petrović Milica M., Najdanović Slobodan M., Bojić A.L. 2015. Comparison of ultraviolet radiation/hydrogen peroxide, Fenton and photo-Fenton processes for the decolorization of reactive dyes. Hemijska industrija, 69(6), 657-665.

28. Rizzo, L. 2011. Bioassays as a tool for evaluating advanced oxidation processes in water and wastewater treatment. Water Research.

29. Spanggord, R., Mabey, W.R., Chou, T.W., Lee,S. A., Philip L.1983. Environmental Fate Studies of HMX. p. 61.

30. Zhai, J., Ma H., Liao J., Rahaman H.M., Yang Z., Chen Z. 2018. Comparison of Fenton, ultravioletFenton and ultrasonic-Fenton processes on organics and colour removal from pre-treated natural gas produced water. International Journal of Environmental Science and Technology, 15, 2411-2422. 